\title{
THE FIRST PALEOSEISMIC TRENCH DATA FROM ACIPAYAM FAULT, FETHIYE BURDUR FAULT ZONE, SW TURKEY
}

\author{
Kürçer A. ${ }^{1}$, Özdemir E. ${ }^{1}$, Uygun Güldoğan Ç. ${ }^{1}$ and Duman T.Y. ${ }^{1}$ \\ ${ }^{l}$ Department of Geological Research, General Directorate of Mineral Research and Exploration, \\ 06800 Ankara,Turkey, akin.kurcer@mta.gov.tr
}

\begin{abstract}
The Aclpayam Fault is an active fault segment which is located on the central part of Fethiye Burdur Fault Zone in SW Turkey. According to the Active Fault Map of Turkey published by MTA (Turkey), it is described as a Quaternary fault. Acipayam Fault extends from Acipayam at northeast to Akköprü Dam at southwest. The general strike of fault is $N 35^{\circ} \mathrm{E}$, approximately $60 \mathrm{~km}$ long and it's a normal fault with minor sinistral strike-slip component. The fault is composed of three fault section, which are named as Örenköy, Olukbaşı and Yolçatı, seperated from each other by step-over zones. In this study, active tectonic features of Acipayam fault are investigated and paleoismological trench surveys are perfomed at the Örenköy fault section. Two cross trenches were excavated along the fault. The samples collected from the trenches were dated using the ${ }^{14} \mathrm{C}$ dating method. Örenköy trenches were photographed using the Paleoseismological Three Dimensional Virtual Photography Method, which is a new tecnique for paleoseismology. According to the trench microstratigraphy, structural data and dating results, Acipayam fault is described as a Holocene fault. The date of last event that occurred on the Acipayam fault is between $3030 \pm 30 \mathrm{BP}$ and $2410 \pm$ $30 \mathrm{BP}$.
\end{abstract}

Keywords: Aclpayam fault, Fethiye Burdur Fault Zone, SW Turkey, Paleoseismology, Trench, ${ }^{14} \mathrm{C}$ dating method.

\section{Пврі́ $\eta \psi \eta \eta$}

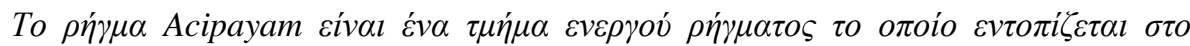

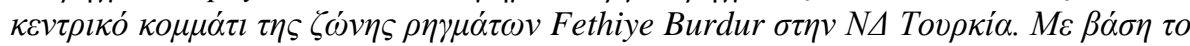

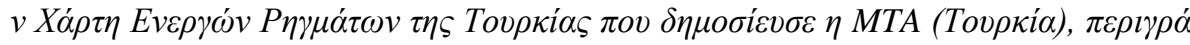

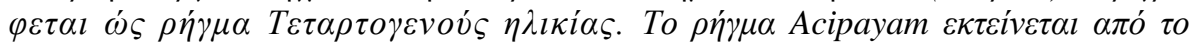

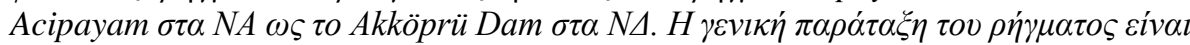

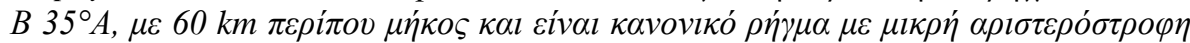

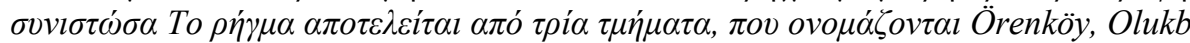

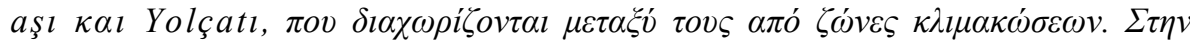

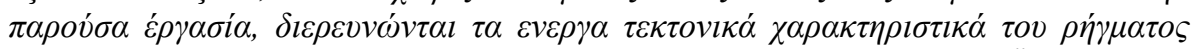

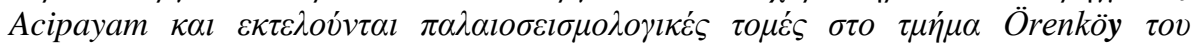

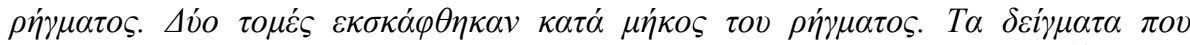

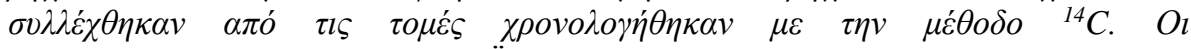

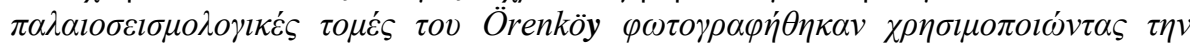

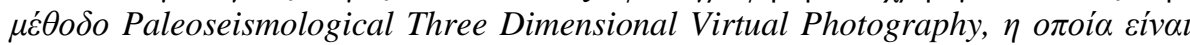

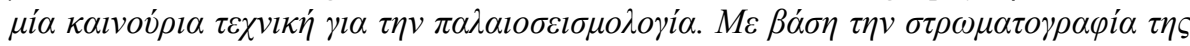




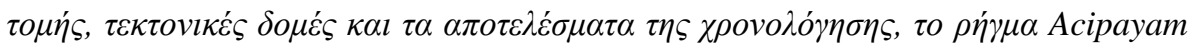

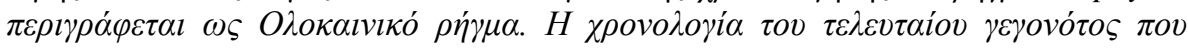

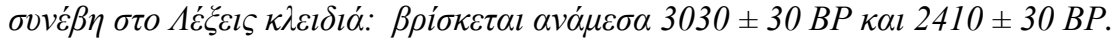

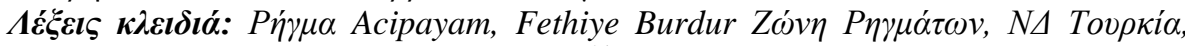

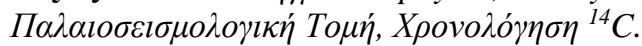

\section{Introduction}

The eastern Mediterranean region, including the surrounding areas of western Turkey and Greece is seismically active and rapidly deforming regions within the continents due to the northward convergence of the African and Arabian plates with respect to the Eurasian plate along a complex plate boundary. As a result of this convergence tectonic processes, the active tectonics of the Anatolian Block and its vicinity is mainly controlled by the intracontinental active fault systems (etc. North Anatolian Fault System, East Anatolian Fault System, Dead Sea Fault Zone, Fethiye Burdur Fault Zone) and the Aegean and Cyprean Subduction Zones (Figure 1).

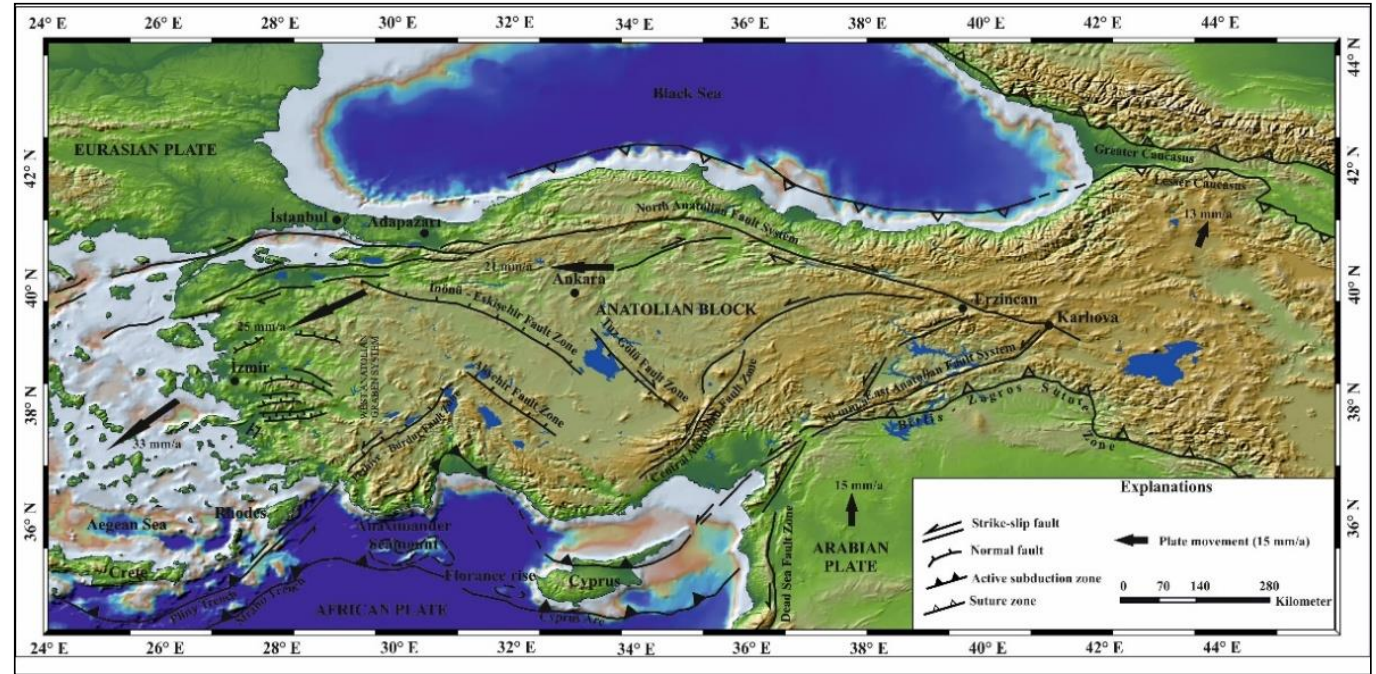

Figure 1 - Simplified active tectonic map of eastern Mediterranean region superimposed on topography (modified from Çiftçi, 2007; Koçyiğit and Özacar, 2003; Kürçer, 2012; Okay et al., 2000; Özsayın, 2007; Woodside et al., 2002; Yolsal-Çevikbilen and Taymaz, 2012; Zitter et al., 2005; Kürçer et al., 2015) Black arrows and corresponding numbers show GPSderived plate velocities (mm-year) (Reilinger et al., 2006). Geomapp Application data were used for the digital elevation model.

The Southwestern Turkey is a complex deformation area which is mainly controlled by the Western Anatolian Graben System (WAGS) and partly by the Fethiye Burdur Fault Zone (FBFZ). Many papers have been published about the seismicity and active tectonics of the SW Turkey and surrounding area (i.e. Dumont et al., 1979; Koçyiğit, 1984; Şaroğlu et al., 1987; Barka and Reilinger, 1997; Yağmurlu, 2000; Yaltırak et al., 2010; Över et al., 2010 and 2013a, 2013b).

The Fethiye Burdur Fault Zone (FBFZ), is first proposed by Dumont et al. (1979) as a sinistral strike-slip fault zone and is the NE extension of Pliny-Strabo trench in to the SW Anatolia. According to the Koçyiğit (1984), the origin of the WAGS is Aegean-Cyprean arc trench system and FBFZ is included in WAGS. Şaroğlu et al. (1987) suggested that the central part of FBFZ is composed of active sinistral strike-slip faults. Based on the GPS studies Barka and Reilinger (1997) claimed that the FBFZ is still an active sinistral strike-slip fault zone. FBFZ is described by Yağmurlu (2000) as a fault zone which is composed of several fault segments whose lengths are varying from 10 to $40 \mathrm{~km}$. According to the Yağmurlu (2000), the FBFZ is a transform fault between 
Cyprus and Hellenic arc. Neotectonic development of the basins (etc. Çameli, Eşen, Burdur) located on the FBFZ were studied by Alçiçek (2007) and Alçiçek et al. (2005, 2006, 2013). Based on the geological and structural data and mammalian fossils three different tectonic phase are identified in these basins. FBFZ is described by Yaltirak et al. (2010) as a sinistral shear zone in $40 \mathrm{~km}$ wide. Late Cenozoic stress state of basins along the FBFZ were studied by Över et al. (2010) and Över $e$ t al. (2013a, 2013b). According to the fault plane slip data and inversion of focal mechanism solutions predominantly stress regime is NW-SE extension. Additionaly May 12, 1971 Burdur earthqauake sequence was studied by Taymaz and Pierce (1991). Based on the seismological data and geological observations the source of this sequence is a normal fault, which is trending NE and dipping NW. Several archaeoseismological studies were performed on the Kibyra ancient city which is located on the central part of FBFZ. Based on the archaeogeological data collected from Kibyra fault is an active sinistral strike-slip fault (Akyüz and Altunel, 1997; 2001; ten Veen et al., 2007; Karabacak, 2011; Karabacak, et al., 2013). In contrast to this view several authors dosen't accept the existence of Kibyra fault (Elitez and Yaltırak, 2014). In order to test of kinematic characteristics of FBFZ, Kaymakçı et al. (2014) had conducted paleomagnetic and kinematic study in the region. Paleomagnetic data, slickenside pitches and contracted paleostress configurations along the FBFZ indicated that the faults in the FBFZ are mainly normal in character. Several paleoseismological studies were performed northern part of the FBFZ (etc. Bozcu et al., 1997; Yağmurlu et al., 2008).

According to the Active Fault Map of Turkey (Emre et al., 2013) active faults in the SW Turkey have been evaluated as normal faults with minor sinistral strike-slip component (Figure 2). Acipayam fault is located on the central part of FBFZ (Figure 3).

This study mainly concerned with the active tectonic and paleoseismological fatures of Acipayam fault. The aim of this paper to understand the Holocene seismic activity of Acipayam Fault. To accomplish this, we have performed paleoseismic trenching along the Accpayam Fault.

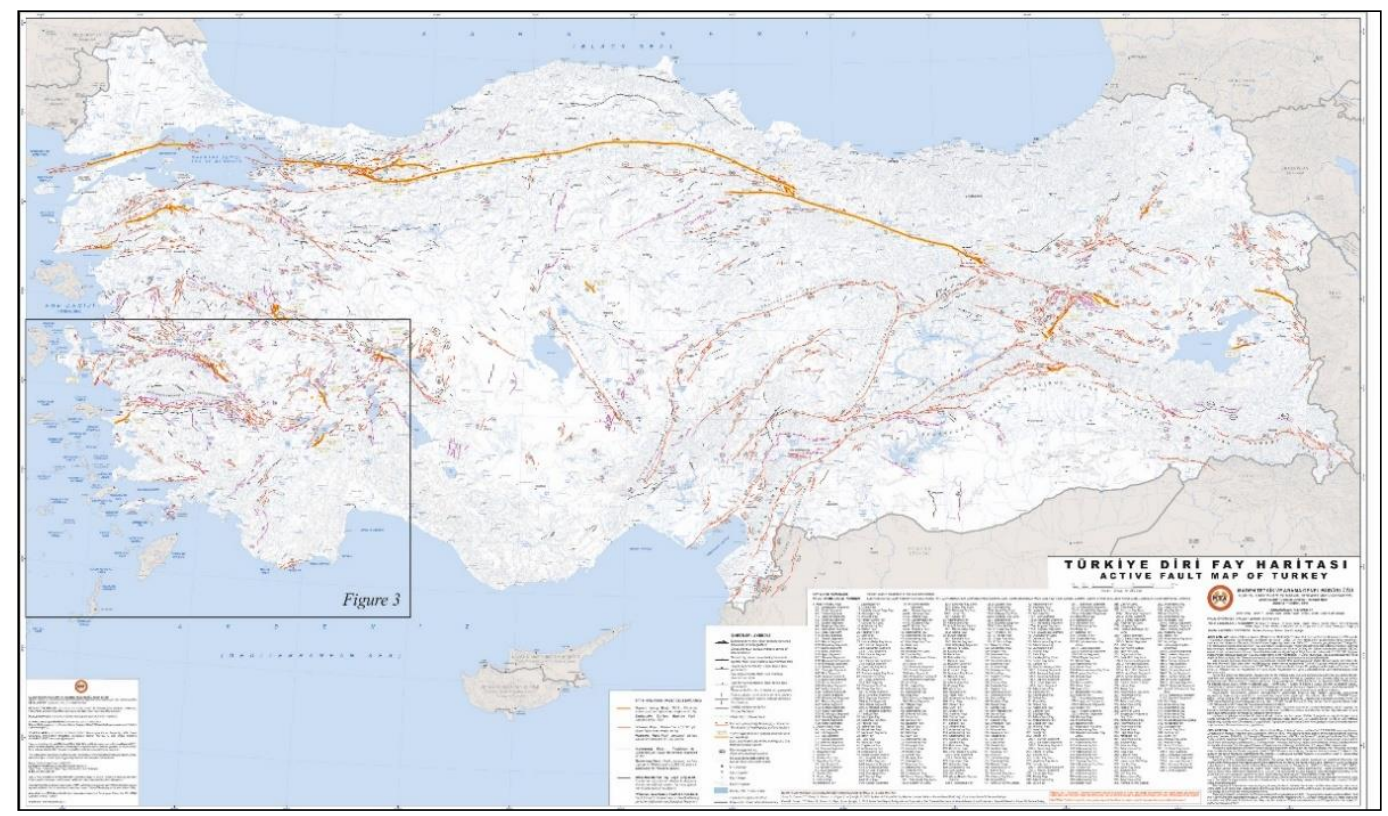

Figure 2 - Active fault map of Turkey (Emre et al., 2013). 


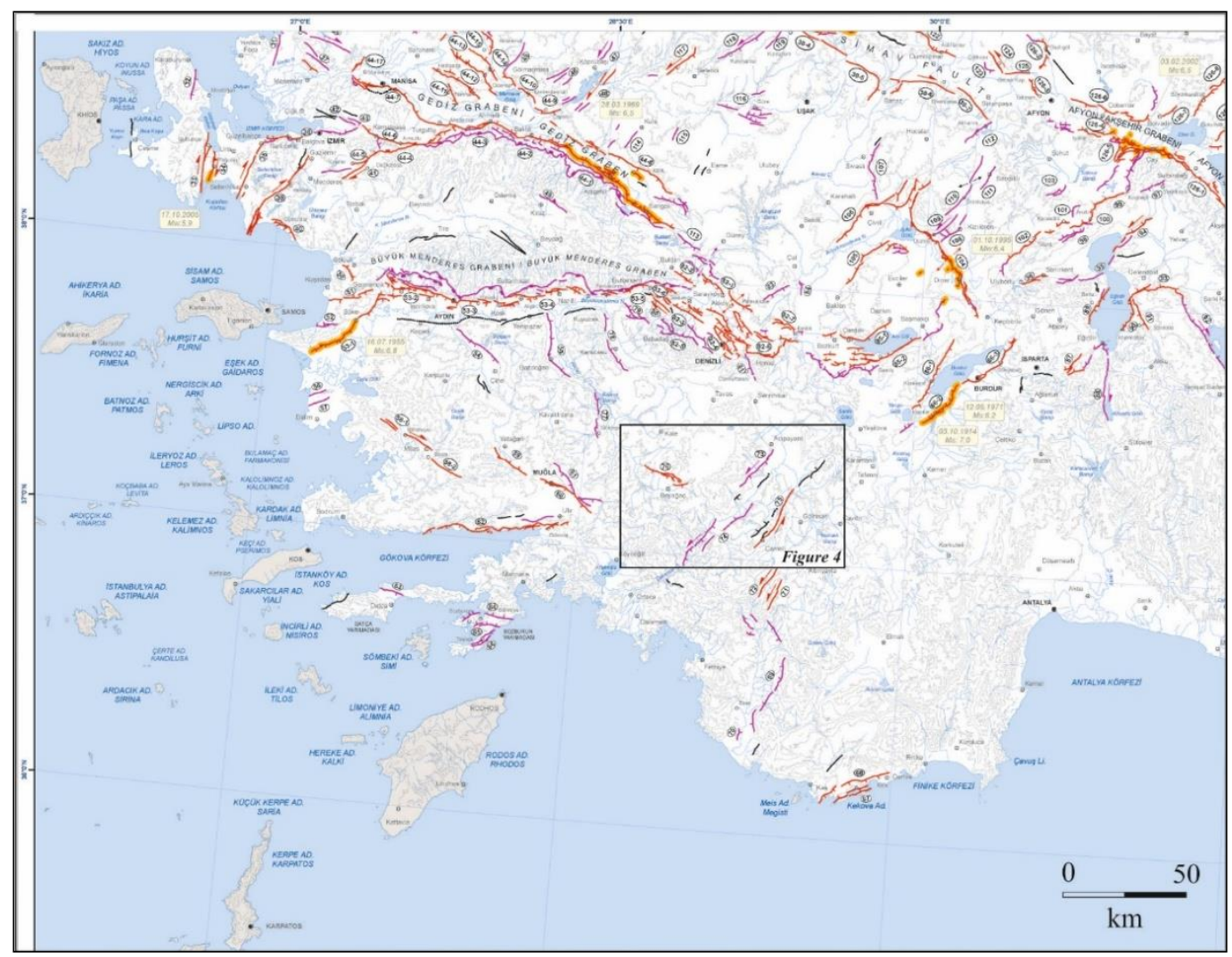

Figure 3 - Active fault map of SW Turkey (Emre et al., 2013). Acipayam fault is represented by number 73 .

\section{Acipayam Fault}

Acipayam Fault (AF) is an active fault which is about $60 \mathrm{~km}$ in length, is characterized by a number of normal faults with minor left lateral strike-slip component (Figure 4). The general strike of AF is $\mathrm{N} 35^{\circ} \mathrm{E}$ and it's composed of three main fault section, which are named as Örenköy, Olukbaş1 and Yolçat, seperated from each other by step-over zones. Mesozoic ophiolitic rocks, Paleocene-Eocene clastics and carbonates, Early Miocene continental clastics, Late Miocene-Pliocene continental and lacustrine deposits and Quaternary fan deposits are cutted by the Acipayam Fault along the fault trace.

The Yolçatı section, which is the southwesternmost part of AF, is $23 \mathrm{~km}$ long normal fault. The central part of AF is called as Olukbaşı section. The length of this section $12 \mathrm{~km}$. Örenköy section which is the northeastern part of AF is $20 \mathrm{~km}$ long a normal fault with minor sinistral strike-slip component.

\section{Paleoseismic Trenching along the Acıpayam Fault}

In this study, two paleoseismological trenches which were parallel to each other were excavated along the Örenköy section of the AF (Figure 4). The fault trace is characterised by a fresh fault scarp on the field (Figure 5). Örenköy trench site, which was selected by aeiral photo analyses, tectonomorphological structures and geological observations, is located at $500 \mathrm{~m} \mathrm{NE}$ of Örenköy in an area where Quaternary alluvial fan deposits (Figure 6). Four samples which were collected from the two trenches and dated in Beta Analitic Laboratory (USA) using the ${ }^{14} \mathrm{C}$ dating method. 


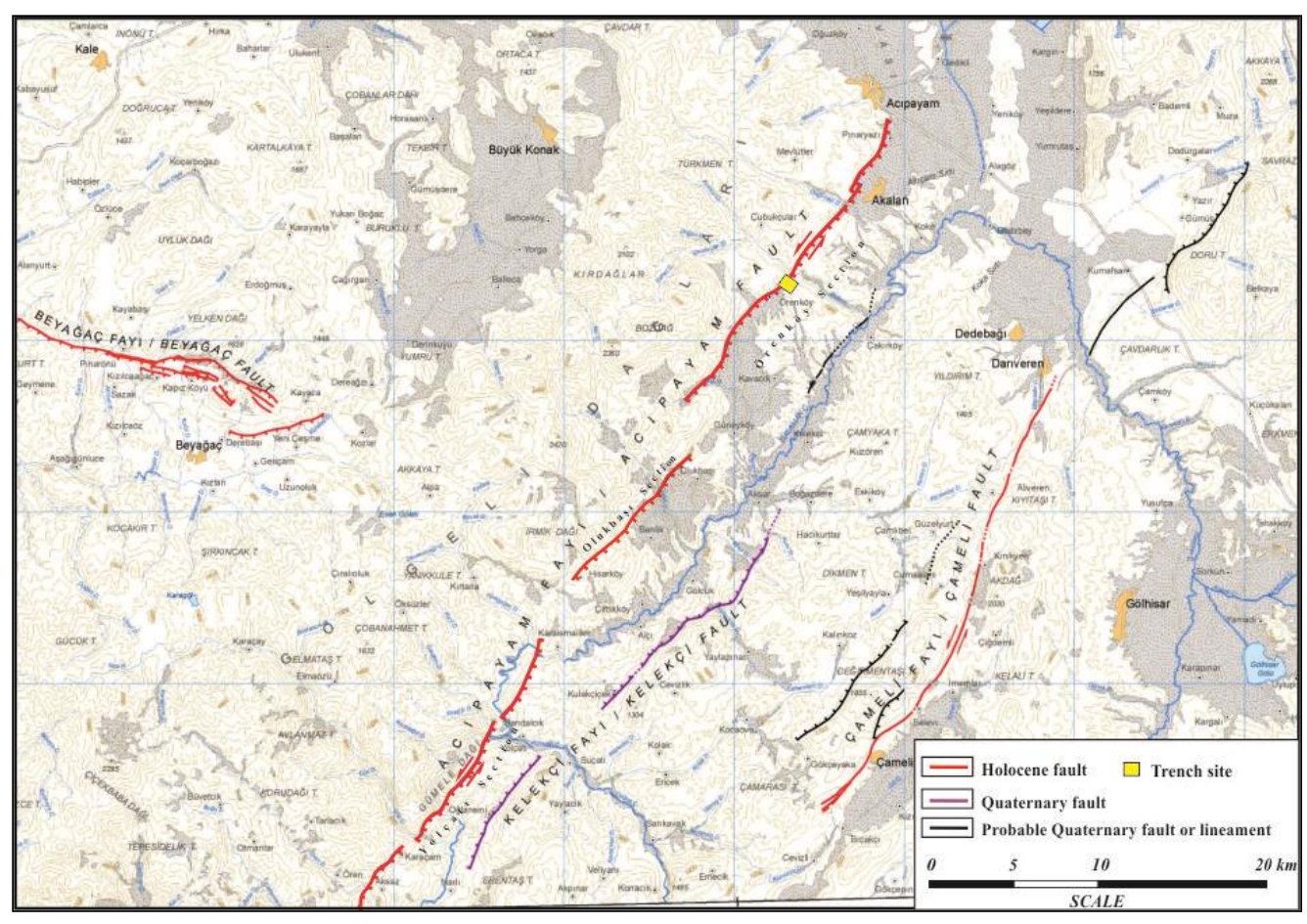

Figure 4 - Active fault map of Acıpayam Fault and its vicinity (Modified from Emre et al., 2011).

The trenches were excavated perpendicular to the direction of Örenköy fault section $\left(\mathrm{N} 40^{\circ} \mathrm{W}\right)$. Here we present the 13 meters of the northern wall of Örenköy Trench 1 exposure to summarize the deformation style and fault characteristics (Figure 7).

Three different sedimentary package were identified on the trench walls. The oldest package was interpreted as Mevlütler formation (Aquitanian-Burdigalian). This formation is consisted of fluvial deposits. The second package is Plio-Quaternary (?) alluvial fan deposits. It's composed of sand, mud and gravel alternation. And the relatively youngest package is consisted of gravel. Based on the ${ }^{14} \mathrm{C}$ dating results the youngest units ( 3 to 7 ) are evaluated as Holocene deposits.

The trenches were photographed using the Paleoseismological Three Dimensional Photography Method which is a new technique for paleoseismology. This method was applied previously in several paleoseismological studies (etc. Kürçer, 2012; Kürçer and Gökten, 2012; Kürçer and Gökten, 2014). 


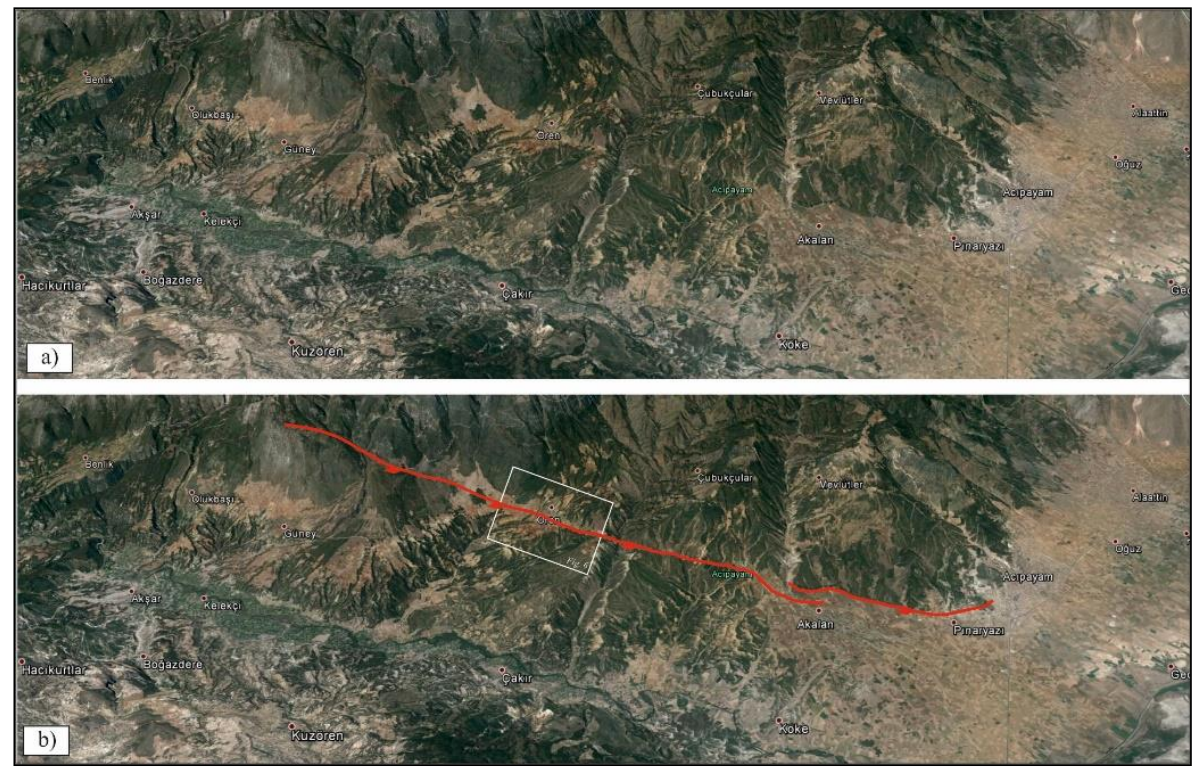

Figure 5 - Google Earth views of the Örenköy Section, (a) Uninterpreted, (b) Interpreted (vertical scale three times exaggerated, view to $W$ ).

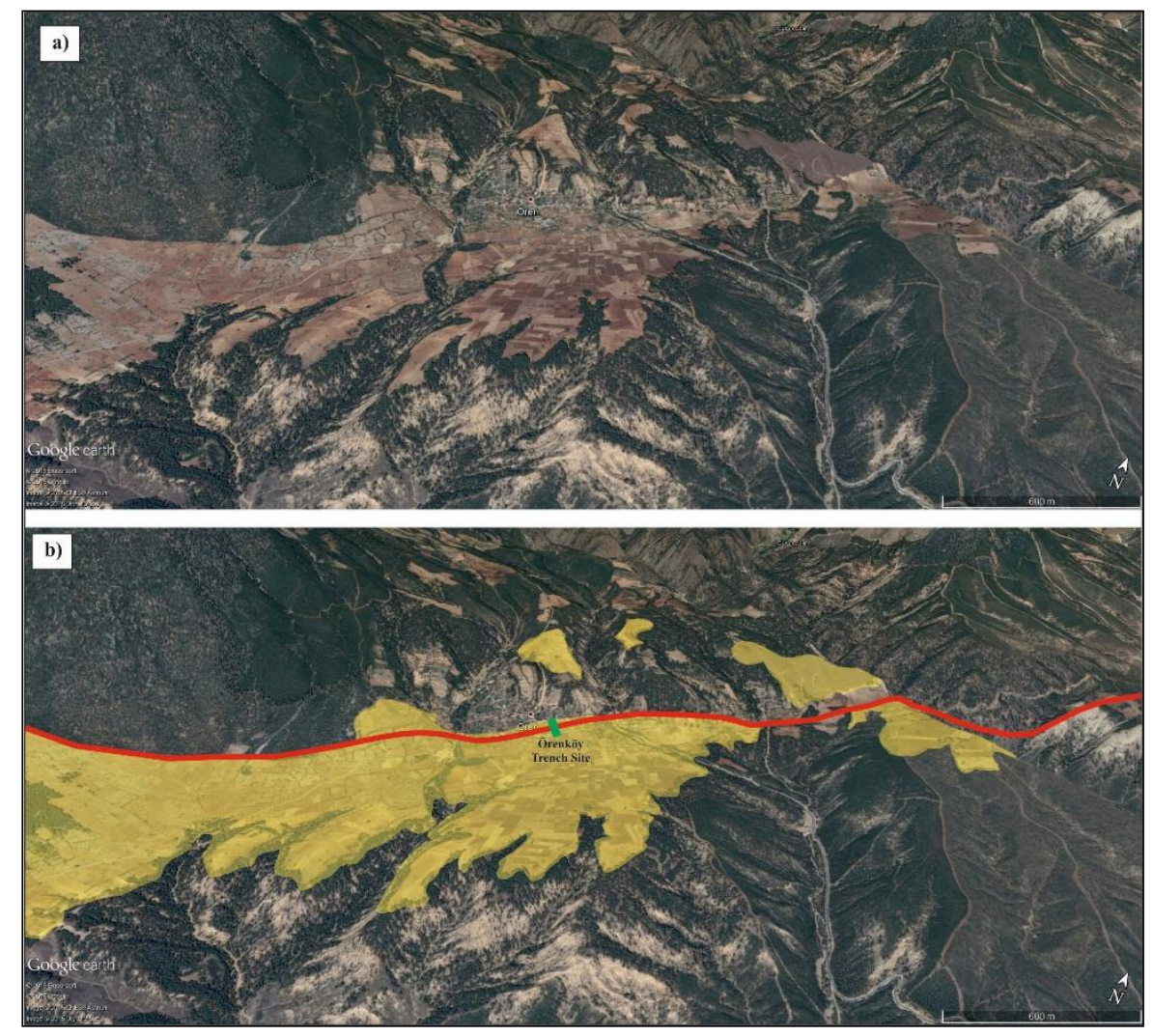

Figure 6 - Google Earth views of the Örenköy Trench site, (a) Uninterpreted, (b) Interpreted (vertical scale three times exaggerated, view to $\mathrm{NW}$ ). 


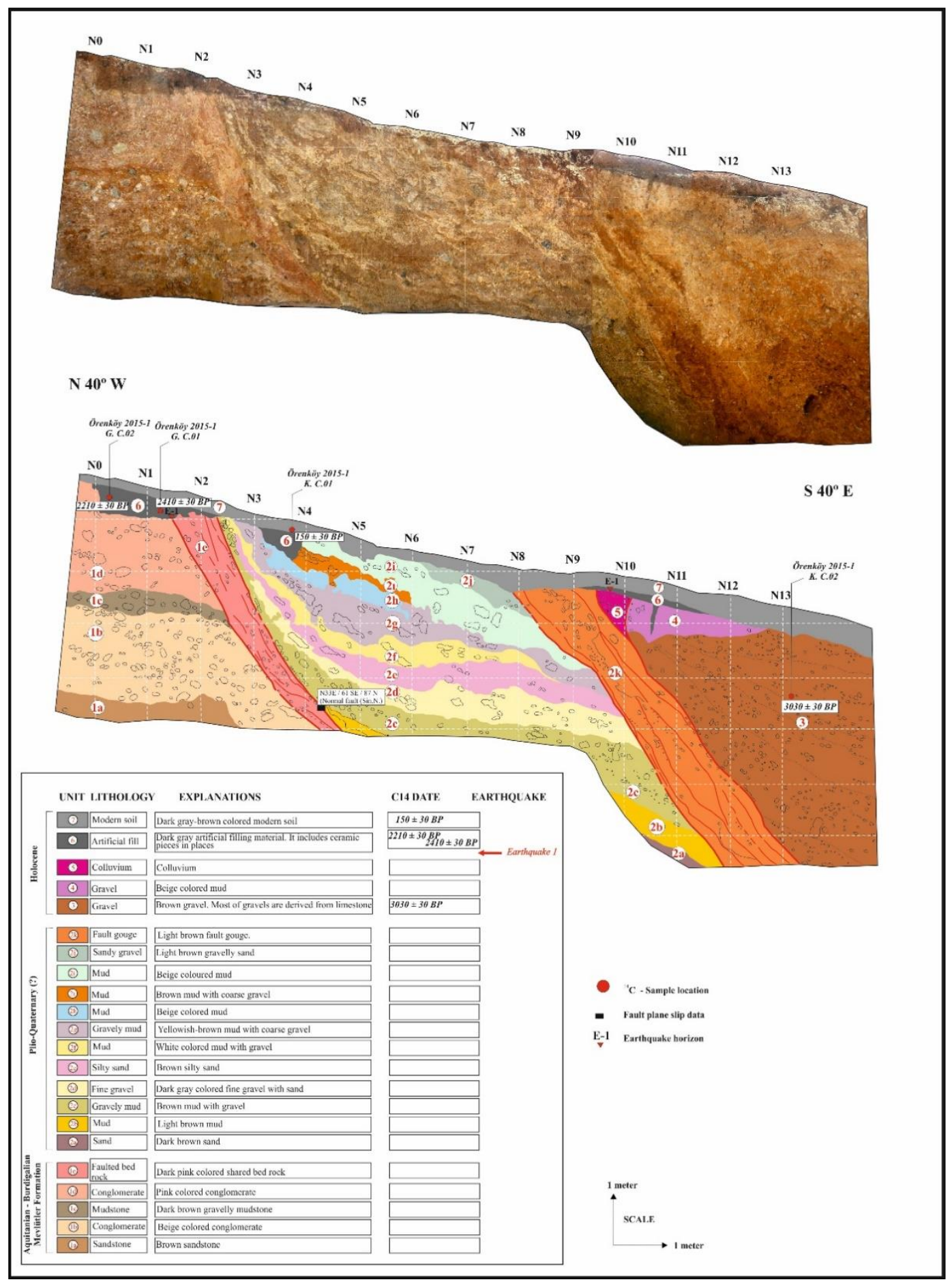

Figure 7 - Photomosaic and Trench log of northern wall of Örenköy Trench 1. 


\section{Discussion and Conclusion}

In this study reliable paleoseismic data were obtained about the Holocene activity of Acıpayam fault. Based on the trench microstratigraphy, structural pattern and ${ }^{14} \mathrm{C}$ dating results the Holocene activity of Acipayam fault revealed precisely. According to the dating results, the last event that occurred on the Acipayam fault was dated between $3030 \pm 30 \mathrm{BP}$ and $2410 \pm 30 \mathrm{BP}$.

Additionaly, based on the structural observations and fault plane slip data measured from trenches, the kinematic characteristics of Acıpayam fault was revealed. According to the fault plane slip data, Acipayam fault is a normal fault with minor sinistral strike-slip component (Figure 7).

\section{Acknowledgments}

The study has been realized in the frame of the Paleoseismological Researches Project of Turkey (TURKPAP). Financial support has been provided by General Directorate of Mineral Research and Exploration of Turkey (MTA). We are also grateful to Dr. Volkan Özaksoy (MTA) for his assistance during the field study (partly). We are thankful to all organizations and executives, and to reviewers for their critics and supports.

\section{References}

Akyüz, H.S. and Altunel, E., 1997. The 417 A.D. Cibyra earthquake: Evidences of left-lateral motion along the Burdur-Fethiye fault zone (SW Anatolia-Turkey). In: First Meeting of Active Tectonics Research Group Abstracts (in Turkish with English abstract), ITU, Istanbul, Turkey, 8-9 December 1997, 161-170.

Akyüz, H.S. and Altunel, E., 2001. Geological and archaeological evidence for post-Roman earthquake surface faulting at Cibyra, SW Turkey, Geodinamica Acta, 14, 1-7.

Akyüz, H.S. and Altunel, E., 2001. Geological and archaeological evidence for post-Roman earthquake surface faulting at Cibyra, SW Turkey, Geodinamica Acta, 14, 95-101.

Alçiçek, M.C., Kazanc1, N. and Özkul, M., 2005. Multiple rifting pulses and sedimentation pattern in the Çameli Basin, southwestern Anatolia, Turkey, Sedimentary Geology, 173, 409-431, doi:10.1016/j.sedjeo.2003.12.012.

Alçiçek, M.C., Ten Veen, J.H. and Özkul, M., 2006. Neotectonic development of the Çameli Basin, southwestern Anatolia, Turkey, Geological Society, Special Publications, 260, 591-611.

Alçiçek, M.C., 2007. Tectonic development of an orogen-top rift recorded by its terrestrial sedimentation pattern: The Neogene Eşen Basin of southwestern Anatolia, Turkey, Sedimentary Geology, 200, 117-140.

Alçiçek, M.C., Mayda, S. and Titov, V.V., 2013. Lower Pleistocene stratigraphy of the Burdur Basin of SW Anatolia, C.R. Palevol, 12, 1-11.

Barka, A.A. and Reilinger, R., 1997. Active tectonics of the Eastern Mediterranean region: deduced from GPS, neotectonic and seismicity data, Annali di Geofi sica, 40, 587-610.

Çiftçi, B., 2007. Geological evolution of the Gediz Graben, SW Turkey: Temporal and spatial variation of the Graben (PhD Thesis, unpublished), Middle East Technical University, Graduate School of Natural and Applied Sciences, Ankara, 290 pp.

Bozcu, M., Yağmurlu, F. and Şentürk, M., 2007. Some Neotectonic and Palaioseismological features of Fethiye-Burdur Fault zone, SW-Anatolia, Geological Engineering, 31(1).

Dumont, J.F., Uysal, Ş., Şimşek, Ş., Karamanderesi, I.H. and Leteouzey, J., 1979. Formations of the grabens in Southwestern Anatolia, Bull. Min. Res. Explor. Inst Turkey, 92, 7-18.

Emre, Ö., Doğan, A., Özalp, S. and Yıldırım, C., 2011. 1:250 000 Scale Active Fault Map Series of Turkey, Denizli (NJ 35-12) Quadrangle. Serial number: 12, General Directorate of Mineral Research and Exploration, Ankara - Turkey.

Emre, Ö., Duman, T.Y., Özalp, S., Elmacı, H., Olgun, Ş. and Şaroğlu, Ş., 2013. Active fault map of Turkey with explanatory text, Ankara: General Directorate of Mineral Research and Exploration, Special Publication Series-30. 
Karabacak, V., 2011. Geological, Geomorphological and Archaeoseismological Observations Along the Cibyra Fault and Their Implications for the Regional Tectonics of SW Turkey, Turkish Journal of Earth Sciences (Turkish J. Earth Sci.), 20, 429-447.

Karabacak, V., Yönlü, O., Doku, E., Kıyak, N.G., Altunel, E., Özudoğru, S., Yalçıner, C.Ç. and Akyüz, H.S., 2013. Analyses of Seismic Deformation at the Kibyra Roman Stadium, Southwest Turkey, Geoarchaeology: An International Journal, 28, 531-543.

Kaymakc1, N., Özacar, A., Özkaptan, M., Koc, A., Gülyüz, E., Lefebvre, C., Uzel, B., Langereis, C. and Sözbilir, H., 2014. Fethiye-Burdur Fault zone: a Myth? The 8th International Symposium on Eastern Mediterrranean Geology.

Koçyiğit, A., 1984b. Intra-plate neotectonic development in Southwestern Turkey and adjacent areas, Bull. Geol. Soc. Turkey, 27, 1-16.

Koçyiğit, A. and Özacar, A., 2003. Extensional neotectonic regime through the NE edge of the Outer Isparta Angle, SW Turkey: New field a seismic data, Turkish Journal of Earth Sciences, 12, 67-90.

Kürçer, A., 2012. Tuz Gölü Fay Zonu'nun Neotektonik Özellikleri ve Paleosismolojisi, Orta Anadolu, Türkiye (Doktora Tezi yayınlanmamış) [Neotectonics and Palaeoseismology of the Tuz Gölü Fault Zone, Central Anatolia, Turkey] (PhD Thesis, unpublished). Thesis no: 318203, Ankara University, Graduate School of Natural and Applied Sciences, Ankara, 318 pp.

Kürçer, A. and Gökten, Y.E., 2012. A New Photography Method for Paleoseismological Trenching: "Paleoseismological Three Dimensional Virtual Photography Method", A Case Study: Tuzgölü Fault Zone, Central Anatolia, Turkey, Tectonics - Recent Advances, Sharkov, E., ed., ISBN: 978-953-51-0675-3, InTech, Available from: http://www.intechopen.com/books/tectonics-recent-advances/paleoseismological-threedimensional-virtual-photography-method-a-case-study-ba-larkayas-2010-trench.

Kürçer, A. and Gökten, Y.E., 2014. Paleosismolojik Üç Boyutlu Sanal Fotoğraflama Yöntemi; Örnek Çalı̧̧ma: Duru-2011 Hendeği, Tuz Gölü Fay Zonu, Orta Anadolu, Türkiye, Türkiye Jeoloji Bülteni, 57,1, 45-71.

Kürçer, A., Yalçın, H., Gülen, L. and Kalafat, D., 2015. 8 January 2013 Mw = 5.7 North Aegean Sea earthquake and its seismotectonic significance, Geodinamica Acta, 27(2-3), 175-188, doi:10.1080/09853111.2014.957503.

Okay, A.İ., Kaşlılar-Özcan, A., İmren, C., Boztepe-Güney, A., Demirbağ, E. and Kuşçu, İ., 2000. Active faults and evolving strike-slip basins in the Marmara Sea, northwest Turkey: A multichannel seismic reflection study, Tectonophysics, 321, 189-218.

Över, S., Pinar, A., Özden, S., Yılmaz, H., Ünlügenc, U.C. and Kamacı, Z., 2010. Late cenozoic stress field in the Cameli Basin, SW Turkey, Tectonophysics, 492, 60-70.

Över, S., Özden, S., Yılmaz, H., Pınar, A, Ünlügenç, U.C. and Kamacı, Z., 2013a. Plio-Quaternary stress regime in Eşen Çay Basin, SW Turkey, Geological Society, Special Publications, doi:10.1144/SP372.19.

Över, S., Yılmaz, H., Pınar, Özden, S., Ünlügenc, U.C. and Kamacı, Z., 2013b. Plio-Quaternary Stress State in the Burdur Basin, SW-Turkey, Tectonophysics, 588, 56-6.

Özsayın, E., 2007. İnönü-Eskişehir fay sisteminin Yeniceoba-Cihanbeyli (Konya-Türkiye) arasındaki bölümünün Neojen-Kuvaterner yapısal evrimi (Doktora Tezi (unpublished)) [Neogene-Quaternary Structural Evolution of the İnönü-Eskişehir fault system in the area between Yeniceoba and Cihanbeyli (Konya-Turkey)] ( $\mathrm{PhD}$ Thesis, unpublished). Hacettepe University, Graduate School of Natural and Applied Sciences, Department of Geological Engineering, Ankara, $120 \mathrm{pp}$.

Reilinger, R., McClusky, S., Vernant, P., Lawrence, S., Ergintav, S., Cakmak, R., Ozener, H., Kadrov, F., Guliev, I., Stepanyan, R., Nadarya, M., Hahubia, G., Mahmoud, S., Sakr, K., ArRajeh, A., Paradissis, D., Al-Aydrus, A., Prilepin, M., Guseva, T., Evren, E., Dmitrotsa, A., Filikov, S.V., Gomez, F., Al-Ghazzi, R. and Karam, G., 2006. GPS constraints on continental deformation in the Africa-Arabia-Eurasia continental collision zone and 
implications for the dynamics of plate interactions, Journal of Geophysical Research, 111, B05411.

Şaroğlu, F., Emre, Ö. and Boray, A., 1987. Türkiye'nin Diri Fayları ve Depremsellikleri, MTA Genel Müdürlügü̈, Rapor No: 8174, 394 pp., Ankara - Türkiye.

Taymaz, T. and Price, S., 1992. The 1971 May 12 Burdur earthquake sequence, SW Turkey: a synthesis of seismological and geological observations, Geophysical Journal International, $108,589-603$.

Ten Veen, J.H., Alçiçek, M.C., Boulton, S. and Ozkul, M., 2007. The role of the Fethiye-Burdur fault zone in the neotectonic evolution of SW Turkey - a combined geological / geoarcheological approach, Geopysical Research Abstracts, 9, 01711.

Yağmurlu, F., 2000, Burdur fayının sismotektonik özellikleri: Batı Anadolu'nun depremselliği sempozyumu, Bildiriler, 43-152, İzmir.

Yağmurlu, F., Özgür, N., Pavlides, S., Chatzipetros, A. and Uysal, K., 2008. Seismotectonic features of Aegean-Peloponnisos plate and the position of the Fethiye-Burdur Fault Zone, SW Turkey, 33nd International Geological Congress, Oslo, Norway, 6-14 August 2008, Abstracts.

Yaltırak, C., Elitez, İ., Aksu, A., Hall, J., Çiftçi, G., Dondurur, D., Akkök, R., Küçük, M. and Güneş, P., 2010. The Relationship and Evolution of the Burdur-Fethiye Fault Zone, the Rhodes Basin, Anaximander Seamounts, the Antalya Gulf and the Isparta Angle since Miocene to Recent in Tectonics of the Eastern Mediterranean, 63. Türkiye Jeoloji Kurultayl, 5-9 Nisan 2010, Ankara.

Woodside, J.M., Mascle, J., Zitter, T.A.C., Limonov, A.F., Ergün, M., Volkonskaia, A. and shipboard scientists of the PRISMED II Expedition, 2002. The Florence Rise, the western bend of the Cyprus arc, Marine Geology, 185, 177-194.

Yolsal-Çevikbilen, S. and Taymaz, T., 2012. Earthquake source parameters along the Hellenic subduction zone and numerical simulations of historical tsunamis in the Eastern Mediterranean, Tectonophysics, 536-537, 61-100.

Zitter, T.A.C., Huguen, C. and Woodside, J.M., 2005. Geology of mud volcanoes in the eastern Mediterranean from combined sidescan sonar and submersible surveys, Deep Sea Research Part I: Oceanographic Research Papers, 52, 457-475. 